\title{
Comparing centralized and decentralized bio-energy systems in rural China
}

\author{
Guizhen $\mathrm{He}^{\mathrm{a}, *}$, Bettina Bluemling ${ }^{\mathrm{b}}$, Arthur P.J. Mol ${ }^{\mathrm{b}}$, Lei Zhang ${ }^{\mathrm{c}}$, Yonglong Lu ${ }^{\mathrm{a}}$ \\ a State Key Laboratory of Urban and Regional Ecology, Research Centre for Eco-Environmental Sciences, Chinese Academy of Sciences, 18 Shuangqing Road, \\ Haidian District, Beijing 100085, China \\ ${ }^{\mathrm{b}}$ Environmental Policy Group, Wageningen University, Hollandseweg 1, $6706 \mathrm{KN}$ Wageningen, The Netherlands \\ ' School of Environment and Natural Resources, Renmin University of China, Beijing 100872, China
}

\section{H I G H L I G H T S}

- Biomass energy development has become part of the national energy strategy in China.

- The dis-/advantages of decentralized and centralized bio-energy systems are evaluated.

- Bio-energy systems should be selected based on the local circumstances.

\section{A R T I C L E I N F O}

\section{Article history:}

Received 28 April 2013

Accepted 6 June 2013

Available online 29 June 2013

Keywords:

Centralized bio-energy system

Household bio-digester

Performance evaluation

\begin{abstract}
A B S T R A C T
Under the dual pressures of an energy crisis and rising greenhouse gas emissions, biomass energy development and utilisation has become part of the national energy strategy in China. The last decade has witnessed a strong promotion of both centralised and decentralised bio-energy systems in rural China. The government seems to have a strong preference for centralised (village-based) bio-energy systems in recent years. However, these government-driven systems have not worked without difficulties, particularly regarding economic and technological viability and maintenance. Studies on the advantages and disadvantages of decentralised and centralised bio-energy systems are rare. This study aims to shed light on the performances of these two systems in terms of social, economic and environmental effects. Through interviewing local officials and village leaders and surveying farmers in 12 villages in Shandong Province, it was found that bio-energy systems should be selected based on the local circumstances. The diversity of the local natural, economic and social situations determines the size, place, technology and organisational model of the bio-energy system.
\end{abstract}

(c) 2013 Elsevier Ltd. All rights reserved.

\section{Introduction}

Bio-based energy is a highly controversial issue around the world, due to its potential conflicts with food security and environmental impacts (Cho, 2010; Jin et al., 2006; Kerr, 2010; Mol, 2007). Nevertheless, bio-based energy has been incorporated into national energy strategies in many countries, spurred by different driving forces. In China, bio-based energy in the form of bio-digesters in rural areas has been promoted by the government across the country since the 1950s, mainly with the intention of supplying gas for cooking in villages that had no access to other energy sources except firewood, straw residues or manure (China Biogas Society, 2011; Liu et al., 2008). The number of biodigesters reached 7 million in 1976 but declined to 4 million in 1982 due to technical and management problems (Chen, 1981;

\footnotetext{
* Corresponding author. Tel.: +86 10 82428491; fax: +86 1062918177.

E-mail address: gzhe@rcees.ac.cn (G. He).
}

China Biogas Society, 2011). Since the early 1980s, the promotion of household bio-digesters in rural China has been integrated with efforts for improved sanitation and cleaner indoor environments. Consequently, technologies have been greatly upgraded to combine domestic energy production with the handling of waste from household toilets, kitchens, agriculture and livestock (Fan et al., 2011; Gan and Yu, 2008; He, 2010; MOA, 2007). More recently, household bio-energy systems have been complemented with more centralised bio-energy systems at the village level, often related to intensive livestock production.

Recent years have thus witnessed the further promotion of both centralised and decentralised bio-energy systems in rural China (Gosens et al., 2013; Jiang et al., 2011; Li et al., 2010; Zhou et al., 2006). Bio-digester systems have been recognised as an effective solution for increasing pollution from animal farms and agricultural residues. By the same token, bio-digester systems can be well integrated in on-going Chinese programs such as those on a rural circular economy, new countryside construction and ecovillage construction. In 2003, the Ministry of Agriculture (MOA) 


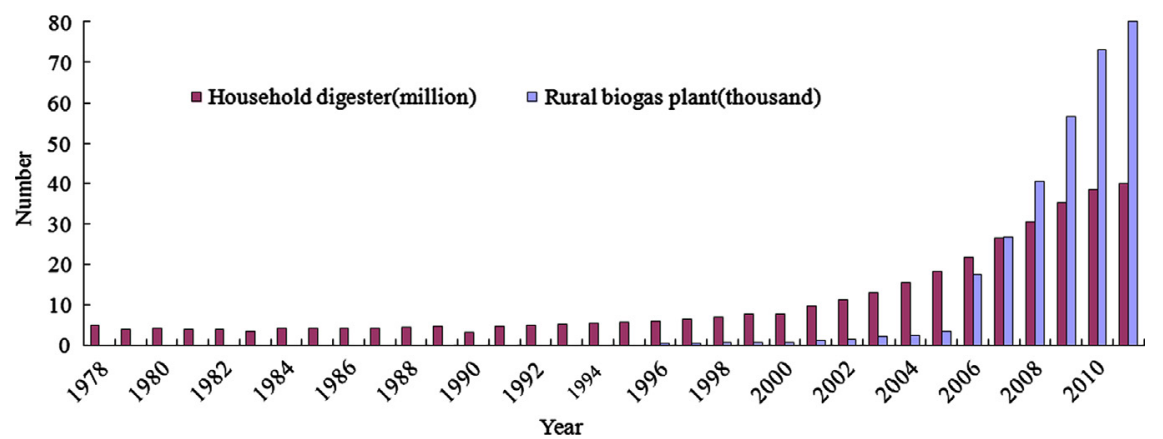

Fig. 1. The number of household biogas digesters and rural centralized bio-energy plants in China, 1978-2011.

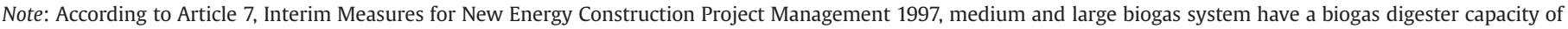
more than $5000 \mathrm{~m}^{3}$ per day. Otherwise the system is defined as a small-scale biogas system.

Sources: Based on Chen et al. (2010), Li et al. (2010), MOA (2008), and Wang et al. (2012).

issued "Measures for the Administration of National Debts for Construction of Biogas Projects in Rural Areas 2003 (Trial)". The Measures insured financial support from the central government for biogas construction and development, and specified the subsidy criteria for household bio-digester construction. Fig. 1 shows that the number of the household bio-digesters increased rapidly since 2004, as well as the centralised digesters since 2006. By the end of 2011, the number of households using biogas increased to nearly 40 million and approximately $33 \%$ of the suitable rural households had bio-digesters. Approximately 80,000 communitybased biogas stations were established, which were mainly based on livestock and poultry farms.

A review of the existing Chinese laws and policies concerning rural development, rural energy and environmental protection shows that the current policy context is very favourable to the further development of bio-energy in rural areas (Zhang et al., 2010; Wang et al., 2010; Zhang et al., 2009). The Agricultural Law of 1973, the Electric Power Act of 1995 and the Energy Conservation Law of 1998 all recognised and emphasised the importance and strategic role of using renewable energy to contribute to the country's energy security, to reduce emissions and to protect the environment. The Renewable Energy Law of the Peoples' Republic of China, issued in 2005 and amended in 2009, is considered a milestone in China's development of a rural renewable energy policy. The Law aims to boost China's renewable energy capacity to $15 \%$ by the year 2020 and outlines a commitment to invest $\$ 180$ billion in renewable energy over this period. The recently (September 2011) issued "12th Five-Year Plan for Agricultural and Rural Economic Development in China" by the MOA proposes to have installed, by the end of 2015, bio-digesters for $50 \%$ of all suitable rural households across China. Recently, however, the Chinese central governments had a growing preference for centralised (village-based) bio-energy systems over household systems. Centralised systems better fit into the government's line of separating land use functions within villages, with raising livestock or energy production distinct from residential areas. Furthermore, with centralised systems, monitoring of their correct operation is more feasible.

Is this preference of the Chinese governments for centralised bioenergy systems in line with better performance of these centralised systems? Most of the existing studies on biogas digesters in China have focused on one of the two systems or on one aspect (economic, environmental performance, social preferences, etc.) of these two technologies (Chen et al., 2010; Gao et al., 2010; Han et al., 2008; Li et al., 2010; Mangoyana and Smith, 2011; Zhang et al., 2008). Studies that give an overall assessment and comparison of the advantages and disadvantages of the two technologies are rare. A general preference for centralised bio-energy systems does not appear to be based on strong evidence yet. In addition, one can question whether a general preference for one type of system holds under all types of circumstances. The choice between "centralised" and "decentralised" options for (bio-energy) systems lies at the core of many debates on environmental performances, economic benefits, and social effects of infrastructures, ever since the publication of Schumacher's "Small is Beautiful" (Schumacher, 1973). Increasingly, however, scholars argue that there is no one best system that fulfils our economic, environmental and social preference. Furthermore, as Grin argues, the answer may be found in the plural, as there is no single best solution, no "single truth" (Vo $\beta$ et al., 2006). At the same time, this does not mean that "anything might go" in the sustainable development of infrastructural systems. The recently emerged modernised mixtures school-of-thought has emphasised that socio-technical systems should be optimised against the specific context in which these systems are used (Hegger, 2007; Oosterveer and Mol, 2010; Scheinberg and Mol, 2010). To put it differently: good and sustainable performance of infrastructural systems is based on the context in which such systems are used. Hence, it depends on the local context whether infrastructural systems are preferably organised, designed and/or implemented in a centralised or decentralised mode. In the following this school-ofthought, the question thus should not be whether general centralised bio-energy systems should be preferred above decentralised ones; the question concerns under what circumstances centralised bio-energy systems should be preferred above decentralised ones in rural China and vice versa.

This paper aims to contribute to a more evidence-based governmental policy on stimulating centralised and decentralised bio-energy systems in rural China, by comparing the advantages and disadvantages of both bio-energy systems in rural China and concluding under which conditions each should be stimulated. To do so, the next section outlines the research methodology. Subsequently, the organisational modes and the strengths and weaknesses of both centralised and decentralised bio-energy systems are assessed with respect to environmental performance, economic performance and social preferences and effects. Finally, conclusions are formulated.

\section{Research methodology}

\subsection{Performance evaluation}

The performances of centralised and decentralised biogas systems are evaluated and compared with respect to three sets of criteria: economic performance, environmental performance and social effects and user preferences. For economic performance, the focus is on the costs and benefits of the two systems, both for the system as a whole and for rural households. Environmental performance is related to the degree in which the system influences the state of the environment (impact) with respect to energy 
production, reduced firewood use, chemical fertiliser and pesticide savings and greenhouse gas emission reduction. User preferences and social effects relate to satisfaction of farmers and the effects on (especially female) household members' workload (saving cooking time, saving fire wood and straw collection, collecting inputs for bio-digesters) and maintenance work (e.g., emptying sludge, repairing).

\subsection{Survey area selection}

Shandong Province was selected because it is the largest energy-consuming province and has strongly promoted biogas systems (Shandong Provincial Bureau of Statistics, 2010). Biomass has a large potential to become a major renewable energy source for Shandong. Around 1997, China started a new round of bioenergy demonstration projects in rural areas, and Shandong was defined as one of the implementation provinces.

Through a pre-survey in April 2010, three cities in Shandong were selected for this research: Dezhou, Zibo and Weifang city (Fig. 2). "City" refers here to an administrative unit in China that ranks below a province but above a county; it does not refer to an urban entity. The most important criteria for city selection were the widespread implementation of both types of biogas digesters. Weifang city and Zibo city were two (out of three) cities of Shandong Province which implemented demonstration projects of the national bio-energy program organised by MOA and the National Development and Reform Commission (NDRC) in 2004.
Since 2006, Dezhou city has initiated pilot projects of villagebased bio-energy stations which use straw stalk fermentation and biomass gasification.

In these three cities, 12 villages were identified based on criteria including economic situation, location and the type to bio-energy system through discussions with local officials of the Bureau of Agriculture. Of the four villages with centralised bio-energy stations, two villages (HC and CW) are from Dezhou city and two villages (XS and HX) are from Zibo city; XS and HX are two villages with collective incomes. Currently, there is one village-owned cattle farm providing the material for biogas station in XS. In HX, the village head is also the owner of a cattle farm. Of the eight villages using household bio-digesters, four villages (DC, ML, CJ and DZ) are in Weifang city and the other four villages are in Dezhou city. Table 1 shows the basic state of affairs in the 12 selected villages with respect to a number of key variables.

\subsection{Data collection and analysis}

This study makes an overall comparison and evaluation of two bio-energy systems, mainly through interviewing and surveying local officials, village leaders and local farmers in 12 villages in Dezhou, Zibo and Weifang cities of Shandong Province. Two methods were employed a series of semi-structured in-depth interviews with six local officials of local Bureaus of Agriculture (qualitative data collection) and a survey among 473 farmers and 12 village leaders (village- and household-level questionnaire).

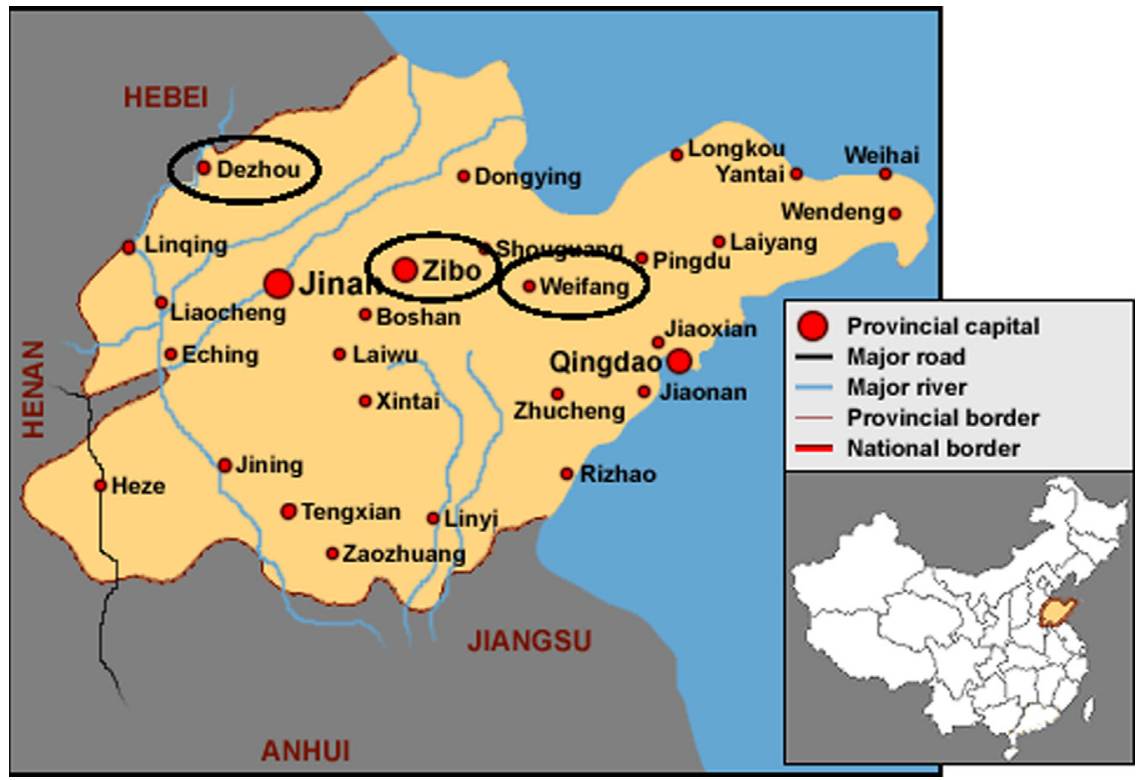

Fig. 2. Case study cities of Dezhou, Zibo and Weifang in Shandong Province, China.

Table 1

Characteristics of the surveyed villages.

\begin{tabular}{|c|c|c|c|c|c|c|c|c|c|c|c|c|}
\hline Items & DC & ML & $\mathrm{CJ}$ & $\mathrm{DZ}$ & MT & SW & SB & $\mathrm{CW}$ & $\mathrm{JZ}$ & $\mathrm{HC}$ & XS & HX \\
\hline Total household & 110 & 240 & 580 & 520 & 262 & 236 & 158 & 230 & 407 & 270 & 330 & 145 \\
\hline Villagers & 350 & 862 & 2200 & 2020 & 1072 & 856 & 580 & 760 & 1500 & 610 & 1172 & 520 \\
\hline Net income per capita (yuan) & 8000 & 7200 & 6000 & 8100 & 6000 & 5000 & 7000 & 7600 & 4500 & 7700 & 8800 & 8500 \\
\hline Electricity use rate $(\%)$ & 100 & 100 & 100 & 100 & 100 & 100 & 100 & 100 & 100 & 100 & 100 & 100 \\
\hline Land $\left(\mathrm{km}^{2}\right)$ & 580 & 1450 & 1600 & 900 & 1948 & 2140 & 1360 & 860 & 2400 & 1090 & 1655 & 600 \\
\hline Poultry farm & No & Yes & No & Yes & No & No & Yes & No & No & Yes & Yes & Yes \\
\hline Bio-energy system & $\mathrm{H}^{\mathrm{a}}$ & $\mathrm{H}$ & $\mathrm{H}$ & $\mathrm{H}$ & $\mathrm{H}$ & $\mathrm{H}$ & $\mathrm{H}$ & $\mathrm{C}^{\mathrm{b}}$ & $\mathrm{H}$ & $\mathrm{C}$ & $\mathrm{C}$ & $\mathrm{C}$ \\
\hline Percent of household using biogas (\%) & 100 & 45.8 & 50 & 24.8 & 51.1 & 58.5 & 6.3 & 87 & 2.5 & 70 & 93.3 & 100 \\
\hline
\end{tabular}

${ }^{\text {a }}$ Household bio-digester.

${ }^{\mathrm{b}}$ Centralized bio-energy system. 
Where possible, these semi-structured interviews were arranged by the first author and recorded through field notes. General interview topics were developed in relation to the main research questions, including the local conditions, the implementation of the biogas system, the construction and maintenance of the bio-digester, the costs and benefits of the biogas systems and the performance of the biogas system.

A questionnaire was designed to understand experiences and opinions of households on bio-digester performance. The questionnaire consisted of mixed open and closed questions and had three sections: (1) socio-demographic characteristics of the household; (2) construction, operation and maintenance of the rural bio-energy system; and (3) experiences with and attitudes towards the bio-energy system. The closed questions also included quantitative data on energy production and costs. In each of the 12 villages, 40 households were randomly sampled. The survey was carried out from April to July 2010 by 10 interviewers. All selected households were informed of the survey by the village leader and then visited by the researchers for a face-to-face interview of the questionnaire. The questionnaire was completed by a member of the household, and responses to some questions were recorded in note-form by the researchers.

SPSS was used for statistical analysis of the survey data. Interview notes were analysed using the framework approach (Mason, 1996; Neuman, 2009), which draws on grounded theory methodology and is suitable for research with a general pre-set aim and where qualitative findings are linked to quantitative data. A total of 473 valid household questionnaires were returned (response rate of 95\%); 320 came from eight villages using household digesters and 153 from four villages with small-scale biogas stations and straw gasification stations. The average family size of the responding households was 3.5 members per household, mostly consisting of three members (37\%), four members (30\%) and two members (18\%). The responding residents were $68 \%$ male and $32 \%$ female. Of the 473 respondents, the age ranged mainly from 30 to 60 years old. A minority of $3 \%$ had a college education, $16 \%$ had completed senior middle school, $51 \%$ junior middle school and $40 \%$ only elementary school. Approximately $78 \%$ were full time farmers, and others were full time or part time off-farm labourers. Over $91 \%$ were not members of any party or group; of the remaining respondents, $2 \%$ were delegates of the village, $3 \%$ leaders of the village and $4 \%$ Communist Party members.

\section{Decision making and operation of different bio-energy systems}

In China, establishing decentralised bio-energy systems are government-organised and -driven process. According to the "Measures for the Administration of National Debts for Construction of Biogas Projects in Rural Areas 2003 (Trial)", the construction of household bio-digesters complies with the principle "government guides, farmers voluntarily participate". The process of establishing decentralised bio-digesters includes several application and approval stages (left in Fig. 3). Normally, the county and township officials will announce and publicise the plan for local

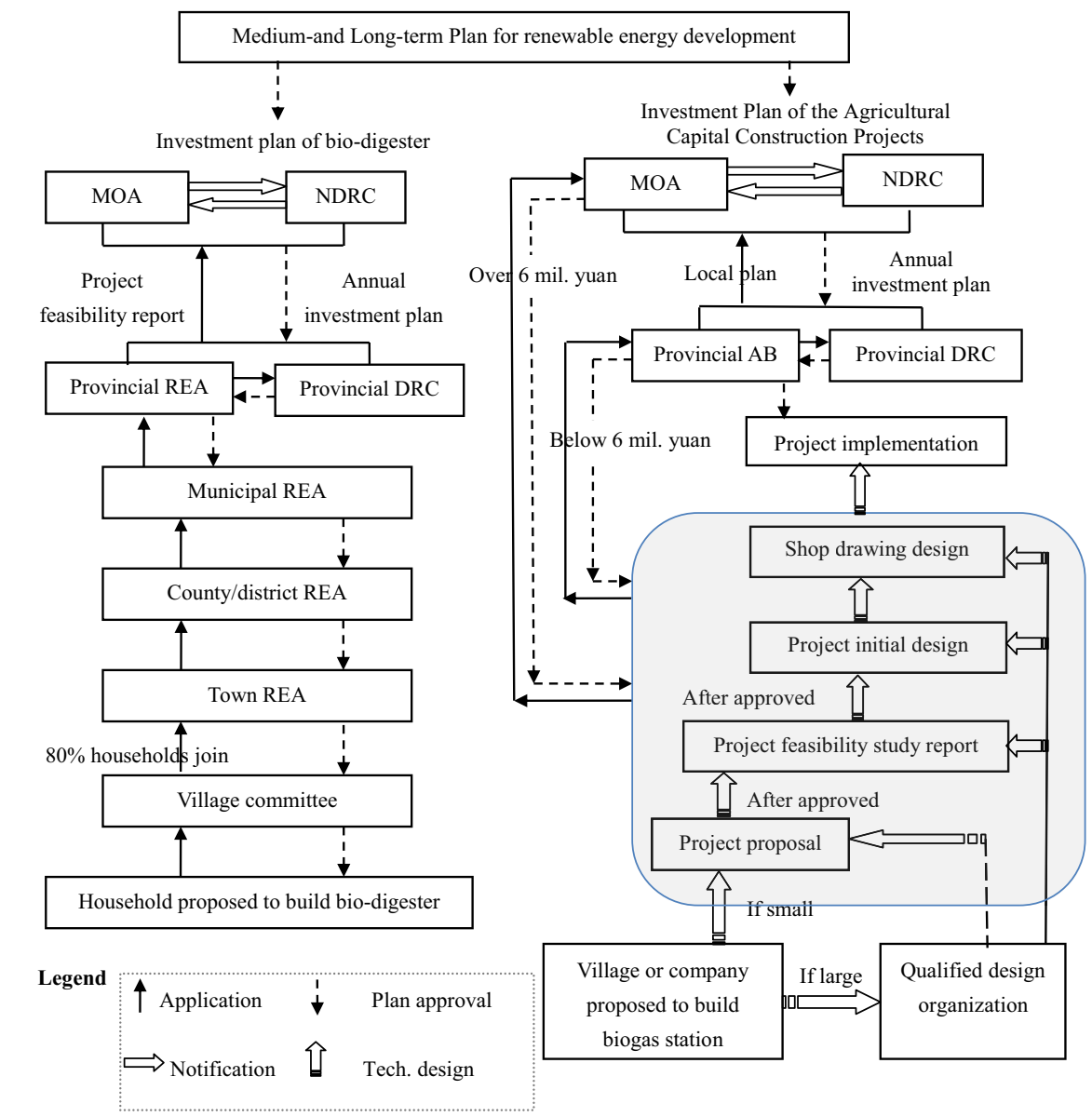

Fig. 3. Application and approval of bio-energy projects in China.

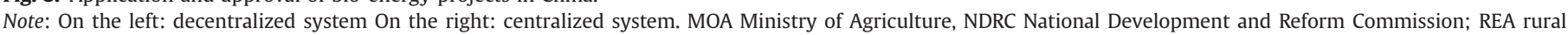
energy agency, $\mathrm{AB}$ agricultural bureau; REA denotes the agricultural, forest, construction agencies responsible for the rural energy in different regions.

Sources: Based on MOA (2003, 2004). 
biogas construction before households' applications. Farmers who propose to build bio-digesters have to inform the village committee. The proposals are then grouped together by the village leaders and reported to the township rural energy agency (REA) if $80 \%$ of the households join the project. In fact, some villages send out proposals with $50 \%$ (even $30 \%$ in some regions) of the households joining to speed-up and promote local biogas construction. The township REA checks the village proposals and submits it to the local county REA. The county REA compiles several township proposals and submits it as a proposal to the city REA. The city proposal is then reported to the provincial REA (mostly under the Bureau of Agriculture, sometimes an independent agency). Provincial REAs are responsible for preparing feasibility study reports on the bio-digester construction proposals and submit the final feasibility report to MOA and NDRC. Normally, NDRC defines the annual construction plan based on the medium- and longterm plan for renewable energy development. NDRC formulates the capital spending plan and MOA details the annual budget and construction plan and informs provincial REAs on the type, criteria, scale and location of bio-digester construction. Then, the plan is subdivided into different regions, level by level: the national subsidies are appropriated for the regional projects, the local REAs implement the annual plan, and the construction and operation of the biodigesters are organised, supervised, checked and filed by the local township REA.

The application and approval process of a centralised bioenergy system are shown in Fig. 3 (right side). The annual investment and the construction plan for centralised bio-energy systems are also defined by NDRC based on the medium- and long-term plan for renewable energy development. MOA makes the annual budget and construction plan. Before application, the villages or companies who propose to build a centralised bioenergy system have to finish the preparation activities of the project construction, including the project proposal, the feasibility study report, the initial design and shop draw design, by themselves (small systems) or by qualified design organisations (medium- and large-scale systems) and obtain approval from the responsible agencies (e.g., either provincial Bureau of Agriculture of independent agency). Next, the application report is submitted to MOA or the provincial REA for the bio-energy systems with an investment of over or below 6 million yuan (approximately 1 million US\$), respectively. According to the approved certificate of authority, the bio-energy system should be implemented by a qualified construction company and is supervised, inspected, checked, accepted and evaluated by the local township REA.

We investigated who the initiators of the bio-energy systems were in our 12 sample villages. The majority of the initiators was township and county governments (6), followed by village leaders (4) and once, a livestock company. In one village, the leaders and villagers discussed and decided the idea together. The villagers were asked how they decided on whether to build a household bio-digester. Approximately $70 \%$ reported that they followed the governmental notice; approximately $19 \%$ accepted the village leaders' suggestions; and the remaining $11 \%$ did not answer the question. In all villages, household bio-digesters were built by a technical team. Households decided on the size of the digester on the basis of the technician's advice $(60 \%)$ or the standard size of national technical rules (34\%). Approximately 95\% of the households were satisfied with the current sizes. After household biodigester construction, $72.5 \%$ of the households did not experience any malfunctioning. The villages with centralised bio-energy digesters had large-scale dairy farms and sufficient crop wastes, and these centralised bio-energy systems were built by qualified construction companies. Their sizes were defined according to the village size, the number of biogas end-users and the available material sources for the digester. Approximately $86 \%$ of the households were satisfied with the operation and maintenance of centralised bio-energy systems. Approximately 65\% of all biogas users were satisfied with the biogas yield/supply from April to October, but during the remaining months they had to use more coal, electricity and liquid petroleum gas due to a poor yield of biogas in the winter.

\section{Economic performance of bio-energy systems}

Both the village leaders and the farmers who have used biodigesters consider the economic performance of bio-digesters an important factor for investment. Eight village leaders mentioned that fuel cost reduction for farmers was as a very important reason for investing in biogas digesters; three also mentioned the fertiliser value of sludge which could save money on chemical fertilisers and pesticides. In addition, 59\% of the farmers in the eight villages using household bio-digesters and $43.2 \%$ of the farmers in the four villages with centralised bio-energy stations gave a positive assessment of "expenditure reduction of household fuel". The questions remain: are these perceptions correct and do bio-digesters also have an overall positive cost-benefit balance?

\subsection{Centralised digesters}

The four centralised bio-energy systems in Dezhou and Zibo cities mainly consist of material pre-treatment, a reactor/stove, a gas storage tank, cleaning equipment/desulphurisation facility, and gas pipelines. The costs of producing biogas consist of overall investments in equipment and pipelines, as well as installation costs; costs for manure/biomass handling and transportation; costs for use of electricity, water and desulphurising reagents; and labour and maintenance costs. The potential income relates to the sale of biogas and the sale of the sludge as fertiliser (only for $\mathrm{AD}$ station). For each of the four systems, the investment (fixed costs) came from the city and district government, the village and the households. Normally, the village provided the largest part of the investment (46-71\%), and farmers only paid a pipeline fee (100 yuan/household, approximately $1.5-4.6 \%$ of the investment costs). Based on the available data, average total costs were estimated to be $0.72-1.60$ yuan $/ \mathrm{m}^{3}$ gas, of which $31-59 \%$ relates to investment costs and 41-69\% to operation, maintenance and supervision costs (of a 20 year life expectancy of different centralised bio-energy stations; calculated without discounting). The price of the gas was set in different villages between 0.5 and 1.0 yuan $/ \mathrm{m}^{3}$ and the average income (benefit) was $0.3-0.64$ yuan/ $\mathrm{m}^{3}$ gas (Table 2 ).

The results show that the total costs of producing gas outweighed the benefits (not taking any subsidies into account). For the two villages ( $\mathrm{HC}$ and $\mathrm{CW}$ ) without collective income, the district government provided funds of 15,000 yuan per year and identified a qualified company through public bidding for the maintenance of the bio-energy stations. Even when financial support from the local government is included, the systems in these two villages barely strike a balance between the operational costs and revenues; when capital costs are included, all systems have significantly higher costs than revenues. The diversity of fixed and operational costs can be explained by the project location, material supply, adopted technology, local economic levels and village economic capacity. In general, the costs of bioenergy systems in HC and CW are higher than those in XS and HX villages. HC and CW villages are located in Dezhou, Western Shandong, and have relatively low per capita incomes. Labour cost, water and transportation costs and cleaning costs are low, which resulted in low operational costs. $\mathrm{HC}$ and $\mathrm{CW}$ have no villageowned factory to provide financial support, but the local government provided subsidies for the operation of the bio-energy system. 
Table 2

Economic parameters of centralised bio-energy systems in Shandong province (2009). ${ }^{\text {a }}$

\begin{tabular}{|c|c|c|c|c|c|c|}
\hline \multirow[t]{2}{*}{ Items } & & \multicolumn{5}{|l|}{ Village } \\
\hline & & $\mathrm{HC}$ & $\mathrm{CW}$ & XS & $\mathrm{HX}$ & Average \\
\hline Biogas yield & $\left(\mathrm{m}^{3 /} \mathrm{d}\right)$ & 400 & 500 & 600 & 300 & 450 \\
\hline Operational & life (year) & 20 & 20 & 20 & 20 & 20 \\
\hline Number of & served households & 189 & 200 & 308 & 145 & 210 \\
\hline \multirow{4}{*}{ (yuan) } & Total fixed cost & 727,900 & 672,000 & $2,070,000$ & $1,890,000$ & $1,340,000$ \\
\hline & From government & 189,000 & 203,000 & 800,000 & $1,000,000$ & 548,000 \\
\hline & From village/company & 520,000 & 446,000 & $1,240,000$ & 876,000 & 770,500 \\
\hline & From household & 18,900 & 23,000 & 30,000 & 14,000 & 21,475 \\
\hline \multirow{4}{*}{$\begin{array}{l}\text { Operational } \\
\text { cost (yuan/a) }\end{array}$} & Labour cost & 16,000 & 16,000 & 18,000 & 40,000 & 22,500 \\
\hline & Material & 38,000 & 39,000 & 21,000 & 0, self-production & 24,500 \\
\hline & Electricity, water, transportation & 23,500 & 25,000 & 30,000 & 35,000 & 28,375 \\
\hline & Cleaning and maintenance & 2000 & 2000 & 5000 & 5000 & 3500 \\
\hline Benefit & Sale of gas & 65,000 & 68,000 & 50,000 & 40,000 & 55,750 \\
\hline \multirow[t]{2}{*}{ (yuan/a) } & Sale of sludge & 0 & 0 & 0 & 30,000 & 7500 \\
\hline & Township subsidy & 15,000 & 15,000 & 0 & 0 & 7500 \\
\hline \multicolumn{2}{|c|}{ Total cost (yuan $/ \mathrm{m}^{3}$ gas) } & 0.80 & 0.72 & 1.08 & 1.60 & 1.05 \\
\hline \multicolumn{2}{|c|}{ Operational cost (yuan $/ \mathrm{m}^{3}$ gas) } & 0.54 & 0.50 & 0.45 & 0.73 & 0.56 \\
\hline \multicolumn{2}{|c|}{ Benefit without subsidies (yuan $/ \mathrm{m}^{3}$ gas) } & 0.45 & 0.42 & 0.30 & 0.64 & 0.45 \\
\hline \multicolumn{2}{|c|}{ Benefit with subsidies (yuan $/ \mathrm{m}^{3}$ gas) } & 0.55 & 0.51 & 0.30 & 0.64 & 0.50 \\
\hline
\end{tabular}

${ }^{a}$ Interviews with officials of local Bureaus of Agriculture and village leaders.

Table 3

Economic parameters of decentralised bio-digesters in 8 villages of Shandong province (2009).

\begin{tabular}{|c|c|c|c|c|c|c|c|c|c|c|}
\hline \multicolumn{2}{|l|}{ Items } & \multicolumn{9}{|l|}{ Village } \\
\hline & & DC & ML & $\mathrm{CJ}$ & $\mathrm{DZ}$ & MT & SW & SB & $\mathrm{JZ}$ & Average \\
\hline \multicolumn{2}{|c|}{ Number of households with bio-digester } & 110 & 110 & 290 & 129 & 134 & 138 & 10 & 10 & 116 \\
\hline \multicolumn{2}{|c|}{ Average size of bio-digesters $\left(\mathrm{m}^{3}\right)$} & 9.5 & 8.5 & 9.2 & 9.6 & 10.5 & 10 & 8 & 8 & 9.5 \\
\hline \multirow[t]{4}{*}{ Capital cost (yuan) } & Total fixed cost & 2620 & 2704 & 2459 & 2678 & 2742 & 2693 & 2834 & 2653 & 2760 \\
\hline & From government & 1560 & 1182 & 1196 & 1506 & 1771 & 1708 & 1304 & 1320 & 1380 \\
\hline & From village & 0 & 100 & 0 & 500 & 300 & 0 & 0 & 0 & 110 \\
\hline & From household & 1060 & 1422 & 1263 & 672 & 671 & 985 & 1530 & 1333 & 1270 \\
\hline \multirow{3}{*}{ Operational cost (yuan/a) } & Material & 95 & 155 & 98 & 73 & 224 & 187 & 238 & 222 & 178 \\
\hline & Transportation & 25 & 30 & 20 & 30 & 15 & 25 & 15 & 15 & 20 \\
\hline & Cleaning and maintenance & 65 & 70 & 80 & 45 & 53 & 78 & 75 & 68 & 60 \\
\hline \multirow[t]{2}{*}{ Benefit (yuan/a) } & Use of gas & 195 & 207 & 205 & 218 & 215 & 176 & 173 & 166 & 189 \\
\hline & Use of sludge & 318 & 305 & 313 & 356 & 296 & 282 & 245 & 258 & 280 \\
\hline \multicolumn{2}{|l|}{ Total cost (yuan/m³ gas) } & 0.48 & 0.41 & 0.49 & 0.38 & 0.43 & 0.40 & 0.47 & 0.42 & 0.44 \\
\hline \multicolumn{2}{|c|}{ Operational cost (yuan $/ \mathrm{m}^{3}$ gas) } & 0.27 & 0.29 & 0.33 & 0.25 & 0.28 & 0.26 & 0.32 & 0.35 & 0.28 \\
\hline \multicolumn{2}{|c|}{ Benefit (yuan $/ \mathrm{m}^{3}$ gas) } & 0.58 & 0.57 & 0.57 & 0.60 & 0.51 & 0.44 & 0.48 & 0.46 & 0.52 \\
\hline
\end{tabular}

XS and HX are richer villages with high labour, water and cleaning costs. The village-owned or private livestock companies supplied materials with reasonable prices and could also afford the deficits of the bio-energy systems. The HX village committee employed more labour (four farmers) to improve the living standards of the farmers. Local officials and village leaders explained that the bio-digester systems are seen as contributions to the welfare of the local farmers and villages, and not as a purely economic enterprise that should be break-even or even make a profit.

\subsection{Decentralised digesters}

For household digesters, the costs of producing biogas consist of overall digester installation costs (including gas scrubbers) and operational costs. The potential income sources are related to fuel substitution and fertiliser and pesticide substitution due to the use of sludge. Information on costs and benefits was obtained from the 320 existing digester installations in each village, by relating physical size to costs and revenues. In terms of investment in bio-energy systems, the funds came from the central government (800 yuan before 2009; 1000 yuan after 2009 per digester), the provincial and local governments and the villagers. For example, in MT and DZ villages, the county and village governments contributed 300 yuan and 500 yuan, respectively, per digester for the realisation of the "Three in One" eco-agricultural model which combines a biogas digester with a pig pen, a toilet and a biogas stove (Chen et al. 2010). The survey results showed that the average total capital cost per $8 \mathrm{~m}^{3}$ digester was 2800 yuan, of which the central and local governments contribute 1530 yuan, and farmers pay 1070 yuan in cash and non-cash investments, including technician costs, labour costs and installation fees (200 yuan on average, paid by farmers). About half of the investment for a household bio-digester came from governments or the village. The farmer's income in the villages in our study was enough to afford the remaining investment. In our survey, no household built its bio-digester through a loan from a bank.

Annual operational costs for decentralised digesters vary considerably. The operational cost items include material supplies, manure and sludge transportation, maintenance and the sludge removal from the bio-digester for further use. For a family breeding animals, manure is freely available at no cost; otherwise, the family has to buy manure. Based on our survey, 104 households (out of 301 ; $\pm 35 \%$ ) bought animal manure produced by pigs, cows and chickens for their digester in 2009. For those households buying manure, the average spending per household on manure was 178 yuan per digester per year. The average transportation costs including loading and unloading was 20 yuan 
per digester per year. A household can rent someone for 30 yuan per time for removing and transporting the sludge. This was taken to be the equivalent of approximately 50 yuan per digester per year. The average maintenance fee reached approximately 10 yuan per digester.

Before the initiation of bio-digester construction, the energy sources in villages were coal, liquid petroleum gas, electricity and the burning of straw stalks, especially by older people. Based on the available data, the potential economic benefit of synthetic gas/ biogas as a substitute for the former coal and liquid petroleum gas amounted to 190 yuan per household per year. The fertiliser value of sludge was based on the assumption that the use of sludge instead of fertiliser and pesticide use would either save money or increase the productivity and revenue from crops. Revenue from sludge was computed to be 280 yuan per household per year on the basis of fertiliser prices in the surveyed villages.

The assumed lifetime of the digester is approximately 20 years, and no cost discounting was used. The capital costs and operational costs per digester were calculated (see Table 3); according to the available data, total costs were estimated to be $0.44 \mathrm{yuan} / \mathrm{m}^{3}$ gas, distributed between $36 \%$ investment costs and $64 \%$ operation and maintenance costs. Operational costs were 0.38 yuan $/ \mathrm{m}^{3}$ gas and the average revenue was 0.52 yuan $/ \mathrm{m}^{3}$ gas (ranging from 0.44 to 0.60 ; Table 3). From an economic point of view, household digesters have a clear net benefit.

\section{Environmental performance of bio-energy systems}

Village leaders defined the environmental performance of bioenergy systems particularly in terms of cleanliness and sanitation at farmers' homes and in the villages. With bio-digesters, animal manure and organic trash are disposed of at a central domestic place. Five leaders also indicated that the protection of forests and the reduction of soil erosion by replacing firewood with biogas was an important environmental performance parameter. Three mentioned that the use of sludge would reduce the use of chemical fertilisers and pesticides, and thus reduce pollution of local surface and ground water.

Most farmers defined environmental performance of centralised bio-energy systems in terms of improved sanitation at homes and in villages (88\%) and improved energy structure and reduction of pollutant emissions (63.1\%) (Table 4). Few mentioned environmental performance improvements in terms of forest protection and soil erosion, savings on chemical fertilisers and disposal of household waste. The farmers in the eight villages with decentralised bio-digesters gave a positive environmental performance assessment in terms of sanitation improvement (85.3\%), improvement of energy structure and reduction of pollutant emissions (64.5\%) and savings on chemical fertilisers (54.1\%). They also referred to the protection of forests and reduction in water and soil erosion (25.5\%), but less to a reduction in household waste disposal. These farmers indicated that the use of digester sludge saves on average $7.4 \%$ on their chemical fertiliser use and $2.6 \%$ on pesticide use each year. Farmers using centralised biogas did not experience a reduction in the use of chemical fertilisers and pesticides because the sludge was sold to famers with greenhouses and therefore was not freely accessible for all farmers.

Biogas can be a substitute for traditional energy sources in rural areas. The annual average consumption of electricity, liquid petroleum gas (LPG), fuel wood, and crop stalks was reduced by different degrees for both household bio-digester users and centralised bio-energy users compared with non-biogas users (Table 5). Consumption of fuel wood, crop stalks, electricity and LPG reduced distinctly for all biogas users; however, the coal consumption increased, which can be explained by two reasons. First, biogas is mostly used for cooking and heating water but not for heating houses in China, and biogas yield in winter is low and does not cover all energy needs. Thus, local farmers have to use coal stoves to heat their rooms in the winter. Second, the economic conditions of households affect the consumption of coal per household. In our survey, biogas users had more net income (26,357 yuan per year per household) than non-biogas users (20,251 yuan per year per household). Hence, the former can afford higher coal costs than the latter. Overall, the use of biogas reduced the demand for most sources of energy, but did not decrease the demand for coal.

The use of biogas can reduce greenhouse gas (GHG) emissions in two ways by preventing methane emissions through manure treatment and by reducing carbon dioxide emissions through fossil fuel replacement (Zhang et al., 2007). Both methane and carbon dioxide emission reductions may be assessed in terms of kilograms of carbon dioxide equivalents ( $\mathrm{kg} \mathrm{CO}_{2}$-eq). According to Gosens et al. (2013), the total GHG emission reduction of a household bio-digester was $251 \mathrm{~kg} \mathrm{CO}_{2}$-eq per household per year. Using the same calculation method, the total GHG reduction of a centralised bio-energy system amounted to 610 and $589 \mathrm{~kg}$ $\mathrm{CO}_{2}$-eq per household each year in XS and $\mathrm{HX}$, respectively.

Table 4

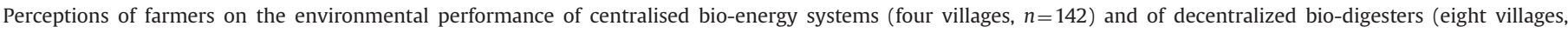
$n=301$ ), Shandong province.

\begin{tabular}{|c|c|c|}
\hline Environmental effects & Centralized bio-energy system (\%) ( $n=142)$ & Decentralized bio-energy system $(\%)(n=301)$ \\
\hline Improve sanitation condition & 88.0 & 85.3 \\
\hline Protect forest and reduce soil erosion & 14.0 & 25.5 \\
\hline Improve energy structure and reduce pollutant emissions & 63.1 & 64.5 \\
\hline Save on chemical fertilizers & 1.7 & 54.1 \\
\hline Dispose household waste & 2.6 & 10.2 \\
\hline
\end{tabular}

Table 5

Annual average consumption of fuels by both biogas users and non-users.

\begin{tabular}{|c|c|c|c|c|}
\hline Fuel type & Unit & Non-biogas user & Household digester user & Centralized bio-energy user \\
\hline Biogas & $\mathrm{m}^{3}$ & 0 & 228 & 276 \\
\hline Coal & $\mathrm{kg}$ & 894 & 1095 & 1132 \\
\hline Electricity & $\mathrm{kWh}$ & 432 & 348 & 361 \\
\hline LPG & $\mathrm{kg}$ & 36 & 20 & 17 \\
\hline Fuel wood & $\mathrm{kg}$ & 384 & 273 & 165 \\
\hline Crop stalks & $\mathrm{kg}$ & 1728 & 1338 & 867 \\
\hline
\end{tabular}


The difference in GHG emission reductions between the centralised and decentralised systems can be attributed to the higher manure content in the centralised bio-digesters for XS and HX systems (approximately 60\% GHG emission reduction) and substitution of biogas for fuel wood and crop stalks (40\% GHG emission reduction).

\section{User satisfaction and social effects of bio-energy systems}

We surveyed the farmers' and village leaders' satisfaction on the achievements of the two bio-energy systems. The village leaders were very satisfied with the goal achievements of the bio-energy systems for improving sanitation at homes (10 out of 12), reducing farmers' expenditure and increasing their income (nine out of 12) and improving sanitation conditions in villages (seven out of 12) (Fig. 4). Two village leaders did not see any goal achievements regarding the reduction in chemical fertilisers, and four were unsatisfied with achievements in improving the ecological environment (protection of forests).

Farmers' satisfaction with achievements of the two bio-energy systems is presented in Figs. 5 and 6. Farmers involved with centralised bio-energy systems had more positive perceptions on the improvement of sanitation at homes and in villages and of energy supply in rural areas, but had more negative opinions on the reduction of chemical fertiliser use than the residents with household digesters. Chi-square tests $\left(\chi^{2}\right.$-test) showed that there were statistically significant positive correlations between the centralised and decentralised bio-energy systems in improvement of the following: sanitation at homes $\left(\chi^{2}=14.509, \quad P=0.002, \quad P<0.01\right)$; sanitation in villages $\left(\chi^{2}=28.436, \quad P=0.000, \quad P<0.001\right)$; energy supply $\left(\chi^{2}=20.430\right.$, $P=0.000, P<0.001)$; reduction of chemical fertiliser $\left(\chi^{2}=63.532\right.$, $P=0.000, P<0.001)$; and reduction of expenditure and increase in income $\left(\chi^{2}=11.848, P=0.018, P<0.05\right)$. There were not statistically significant positive correlations between the centralised and

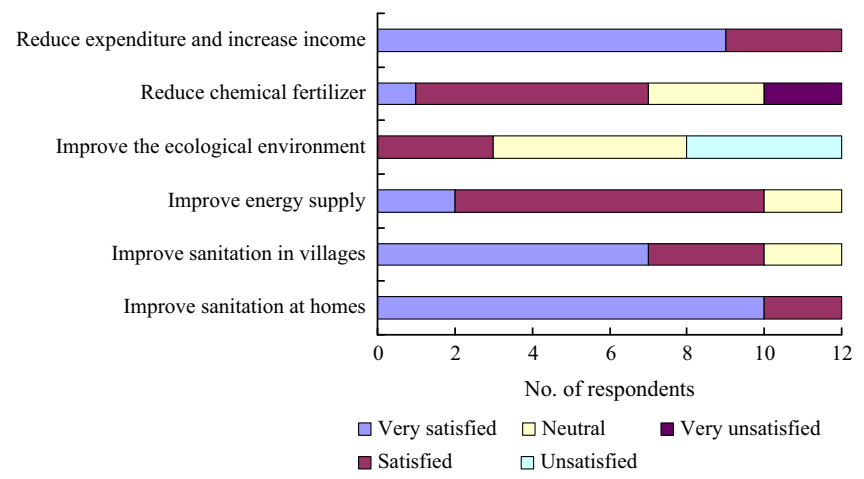

Fig. 4. Village leaders' satisfaction with achievements of bio-energy systems $(n=12)$.

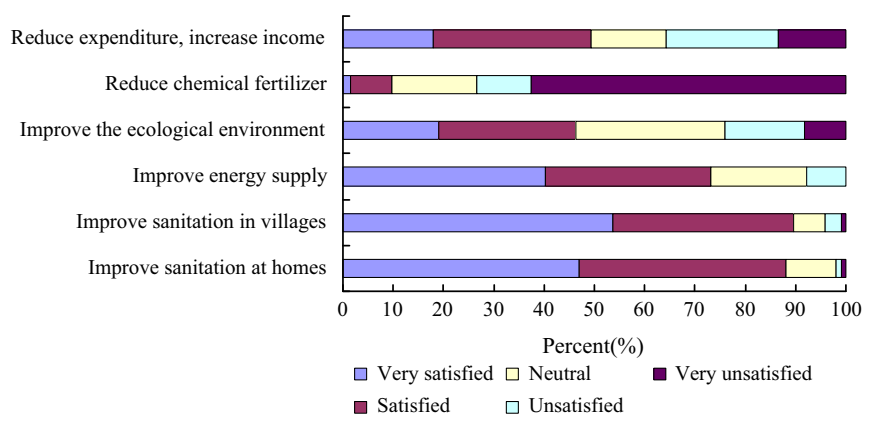

Fig. 5. Farmers' satisfaction with achievements of centralised bio-energy systems $(n=142)$.

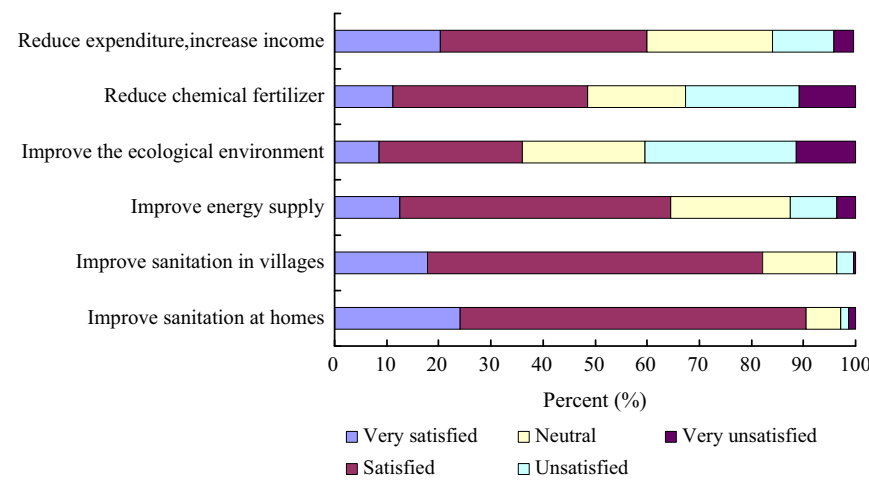

Fig. 6. Farmers' satisfaction with achievements of decentralised bio-digesters $(n=301)$.

decentralised bio-energy systems in improvement of the ecological environment $\left(\chi^{2}=9.295, P=0.054\right)$.

The social effect of different bio-energy systems most mentioned by all village leaders was household convenience. Four village leaders also indicated that centralised bio-energy systems reduced housework load and maintenance work of farmers, referring to the slogan "two people heating-up, all villagers cooking". Therefore, more farmers could increase their income via taking up on-farm or off-farm work. These local officials also noted that construction of the centralised bioenergy systems had a demonstration effect; they were models for other villages tackling rural development, environment and energy security issues. The favourable public image that comes along with these centralised bio-energy systems rewards the governments and village leaders.

Most farmers believed that centralised bio-energy systems had preferential social effects in terms of reduction in the housework load (67.4\%) and reduction in digester energy maintenance workload for each household (63\%). In the eight villages with household digesters, few farmers gave positive assessments of the social effects of household bio-digesters with respect to the reduction in housework load (48\%) and reduction in maintenance workload for each household (31\%).

\section{Comparing bio-energy systems}

Comparing the decentralised household bio-digesters with the centralised village bio-digesters (Table 6) leads to the conclusion that both systems have their (relative) strengths and weaknesses. In general, the organisation, construction, operation and maintenance of decentralised bio-digesters are easier, and their economic performance is superior compared to the centralised bio-energy systems (even though households have to pay more investment costs in contemporary Shandong). However, centralised bio-energy systems have higher energy efficiency, better environmental performance and better social effects.

Accordingly, which system is preferred depends very much on the local context (in terms of physical/material circumstances, economic conditions, governmental policies and subsidies, social preferences of village leaders and users, and main objectives)

\section{Conclusions}

The fast-growing energy demand, the growing concerns over (rural) environmental impacts resulting from the use of conventional fossil fuels, and a number of rural development programs create fertile conditions for the introduction of bio-energy systems in rural China. Developing bio-energy systems is still a government-organised 
Table 6

Assessment of applied centralised and decentralised bio-energy systems in China.

\begin{tabular}{|c|c|c|}
\hline Items & Decentralized bio-system & Centralized bio-system \\
\hline Organization & Easy application and approval, more administrative resources & A little complex, more requirements and qualifications \\
\hline Construction technology & Relatively simple & Relatively complex \\
\hline Operation and maintenance & Relatively simple & Relatively complex, professional required \\
\hline Initial investment & Relatively small, governments subsidies & Relatively big, government subsidies \\
\hline Energy efficiency & Relatively low & Relatively high \\
\hline \multicolumn{3}{|l|}{ Economic performance } \\
\hline for households & Profitable & Not profitable \\
\hline for the system & Profitable & Not profitable \\
\hline Environmental performance & Good & Better \\
\hline Social effects & Reduces workload & Reduces workload even more \\
\hline End-users' satisfaction & User quite satisfied & Users quite satisfied \\
\hline
\end{tabular}

process in China, and the Chinese government has been giving give preference to centralised systems above household bio-digesters.

Comparing the two systems in rural Shandong Province, it can be concluded that both systems have their strengths and weaknesses. Hence, it seems too simple to give an overall preference for centralised systems above decentralised ones. Rather, following the modernised mixture school-of-thought, one could conclude that preference for any of these systems depends very much on the specific local context in which bio-energy is to be developed and used and the set goals.

To further develop bio-energy in China, at least three recommendations can be formulated. First, investment mechanisms should be innovated, streamlined and made more context-dependent. The current multiple funding channels and sources (governments, villages, households) can be combined and differentiated between poor areas and rich areas (where a commercial model with share-holding might work). Second, a stronger relation between long-term environmental and social benefits on one the hand and financial incentives on the other should be established. Systems that perform well in environmental and social terms deserve financial incentives. Third, systems should be selected based on the local circumstances. The diversity of the local natural, economic and social situations determines the size, place, technology and organisational model of the bio-energy system.

\section{Acknowledgements}

This research was financed by the National Natural Science Foundation of China (71103175) and the Netherlands Organization for Scientific Research (NWO) and carried out in the frame of the project RenErGo (Renewable Energy Governance in China and the EU, CO-REACH64-090). Also the Royal Netherlands Academy of Arts and Sciences (KNAW) provided financial support (grant 08PSA-E-02). Thanks to officials in Bureau of Agriculture of Dezhou, Weifang, Linqu, Qingzhou, Linyi, Decheng, Zhutai Township for cooperation and support in the field survey. Also thanks to the reviewers for their comments.

\section{References}

Chen, R.C., 1981. The development of biogas utilisation in China. Biomass 1 (1), 39-46.

Chen, Y., Yang, G.H., Sweeney, S., Feng, Y.Z., 2010. Household biogas use in rural China: a study of opportunities and constraints. Renewable and Sustainable Energy Reviews 14 (1), 545-549.

China Biogas Society, 2011. Review of the development of biogas industry in ChinaRural renewable energy and eco-environment development. Available from 〈http://www.carei.org.cn/index.php?option=com_content\&task=view\&id=1526 .

Cho, A., 2010. Energy's tricky tradeoffs. Science 329 (5993), 786-787.
Fan, J., Liang, Y.T., Tao, A.J., 2011. Energy policies for sustainable livelihoods and sustainable development of poor areas in China. Energy Policy 39 (3) 1200-1212.

Gan, L., Yu, J., 2008. Bioenergy transition in rural China: policy options and co-benefits. Energy Policy 36 (2), 531-540.

Gao, C.Y., Li, T.L., Wang, Y.J., 2010. Current situation, problems and countermeasure of the centralized straw gasification project in China. Journal of Anhui Agricultural Sciences 38 (4), 2181-2183. (in Chinese).

Gosens, J., Lu, Y.L., He, G.Z., Bluemling, B., Beckers, T.A.M., 2013. Sustainability effects of household-scale biogas in rural China. Energy Policy 54, 273-287.

Han, J.Y., Mol, A.P.J., Lu, Y.L., Zhang, L., 2008. Small-scale bioenergy projects in rural China: lessons to be learnt. Energy Policy 36 (6), 2154-2162.

He, P.J., 2010. Anaerobic digestion: an intriguing long history in China. Waste Management 30 (4), 549-550.

Hegger, D. 2007. Greening Sanitary Systems, an End-User Perspective. Ph.D. Dissertation, Wageningen University, Wageningen, The Netherlands.

Jiang, X.Y., Sommer, S.G., Christensen, K.V., 2011. A review of the biogas industry in China. Energy Policy 39 (10), 6073-6081.

Jin, Y.L., Ma, X., Chen, X.N., 2006. Exposure to indoor air pollution from household energy use in rural China. Social Science \& Medicine 62, 3161-3176.

Kerr, R.A., 2010. Do we have the energy for the next transition? Science 329 (5993), 780-781.

Li, B.Y., Bi, Y.Y., Gao, C.Y., 2010. The current situation, problems and countermeasures of agricultural large-and-medium-scale biogas project development in china. Chinese Journal of Agricultural Resources and Regional Planning 31 (2), 57-61. (in Chinese).

Liu, Y., Kuang, Y.Q., Huang, N.S., Wu, Z.F., Xu, L.Z., 2008. Popularizing householdscale biogas digesters for rural sustainable energy development and greenhouse gas mitigation. Renewable Energy 33 (9), 2027-2035.

Mason, J., 1996. Qualitative Researching. Sage, London.

Ministry of Agriculture (MOA), 2007. National Plan for the Rural Biogas Construction (2006-2010). Science and Technology Education Department of Ministry of Agriculture, Beijing, China (in Chinese).

MOA Science and Technology Education Department, 2008. China Rural Energy Yearbook (2000-2008). China Agriculture Press, Beijing, China. (in Chinese).

MOA, 2003. Measures for the Administration of National Debts for Construction of Biogas Projects in Rural Areas (Trial). Promulgated and Implemented on 26 August, 2003.

MOA, 2004. Measures for the Administration of Agricultural Capital Construction Projects. MOA No.39. Promulgated on 12 July, 2004, took effect on 1 September, 2004.

Mol, A.P.J., 2007. Boundless biofuels? Between vulnerability and environmental sustainability. Sociologia Ruralis 47 (4), 297-315.

Mangoyana, R.B., Smith, T.F., 2011. Decentralised bioenergy systems: a review of opportunities and threats. Energy Policy 39 (3), 1286-1295.

Neuman, W.L., 2009. Social Research Methods: Qualitative and Quantitative Approaches, 7th Edition Allyn \& Bacon, Boston.

Oosterveer, P., Mol, A.P.J., 2010. Biofuels, trade and sustainability: a review of perspectives for developing countries. Biofuels, Bioproducts and Biorefining 4 (1), 66-76.

Shandong Provincial Bureau of Statistics, 2010. Shandong Statistical Yearbook. China Statistics Press, Beijing p. 2010.

Scheinberg, A., Mol, A.P.J., 2010. Multiple modernities; transitional Bulgaria and the ecological modernization of solid waste management. Environment and Planning C 28 (1), 18-36.

Schumacher, E.F., 1973. Small is Beautiful: A Study of Economics as if People Mattered. Blond Briggs, London.

Voß, J.P., Bauknecht, D., Kemp, R. (Eds.), 2006. Reflexive Governance for Sustainable Development. Edward Elgar, Cheltenham.

Wang, F., Yin, H.T., Li, S.D., 2010. China's renewable energy policy: commitments and challenges. Energy Policy 38 (4), 1872-1878.

Wang, X.J., Tu, Y.Z., Chen, X.F., 2012. Development and Suggestions on the household biogas project in China. Agricultural Engineering Technology: New Energy Industry $11,13-16$. (in Chinese). 
Zhang, L.X., Yang, Z.F., Chen, B., Chen, G.Q., 2009. Rural energy in China: pattern and policy. Renewable Energy 34 (12), 2813-2823. (in Chinese).

Zhang, P.D., Li, X.R., Yang, Y.L., 2008. Greenhouse gas mitigation benefits of large and middle-scale biogas project in China. Transactions of the Chinese Society of Agricultural Engineering 24 (9), 239-243. (in Chinese).

Zhang, P.D., Jia, G.M., Wang, G., 2007. Contribution to emission reduction of CO2 and $\mathrm{SO} 2$ by household biogas construction in rural China. Renewable and Sustainable Energy Reviews 11, 1903-1912.
Zhang, X.L., Wang, R.S., Huo, M., Martinot, E., 2010. A study of the role played by renewable energies in China's sustainable energy supply. Energy 35 (11), 4392-4399.

Zhou, Z.R., Chen, Q., Chen, S.F., Wu, W.L., 2006. Discussion on the operation experiences and problems of stalk gasification for central gas supply system. Renewable Energy 6, 33-37. (in Chinese). 